\title{
高速コンテナ船のホイッピングと応力集中部の 疲労強度に関寸る考察
}

\author{
正員角 洋 一* 正員山本善 之** \\ 正員 鈴 木 政 直***
}

Fatigue strength of structural members with high stress concentration of a fast container ship in rough seas

by Yoichi Sumi, Member

Yoshiyuki Yamamoto, Member

Masanao Suzuki, Member

\begin{abstract}
Summary
It has recently been recognized that structural failures of large ocean-going vessels are essentially related to the dynamic stresses induced by bottom and bow-flare slamming in rough seas. Bottom slamming may cause an excessive vertical bending moment in a hull girder which may lead buckling of the upper deck, while bow-flare slamming may cause an excessive torsional moment in the fore-body of high speed ships in oblique waves. Local dents and cracking failures due to slamming are also observed in the fore body of large ships, they might be accelerated by severe corrosion.

In high speed ocean-going ships, cracking failures are sometimes observed in middle and aft parts of the hull girders after passing through a rough sea. Since this type of failure is not necessarily exceptional to newly build ships, it may be caused by low cylce fatigue due to repeated whipping stresses induced by bow-flare slams. In the present paper, fatigue strength is investigated for structural members with high stress concentration factors in the neighbourhood of the front end of the superstructure of a container ship, where the applied stress is composed of a wave induced bending stress including non-linear effects, whipping components of stresses, and possibly coupled vibratory stresses of the superstructure.

Having calculated the dynamic stress components among regular waves in head seas, the fatigue strength of highly stressed portions are examined by using appropriate $\mathrm{S}-\mathrm{N}$ curves, in which effects of ship speeds and wave heights are taken into considerations. When a high speed vessel passes through very rough seas, the fatigue strength may be reduced due to the significant elevation of the repeated stress range caused by the whipping components of stresses superposed on the wave induced bending stress.
\end{abstract}

\section{1 序論}

荒天時における大型船の損傷原因として，スラミング こよる船体の動的応答によって誘起される過大な応力が 重要であることが，最近の研究で明らかにされてきた。 スラミングによって船の広い範囲に発生する損傷として は，糈曲げモーメントによる折損 ${ }^{1), 2)}$, 船首部船側フレ ア部に加わる過大な圧力による船首部の捩れモーメント に起因する座屈およびき裂損傷を伴う大変形 ${ }^{3}$, さらに

* 横浜国立大学工学部

** 東京電機大学理工学部

*** 横浜国立大学大学院(現在石川島播磨重工業(株))
船首タンク部外板の腐食および腐食疲労による脱落など がある4),5)。スラミングを直接うける部分に発生する局 部的な損傷としては, 船首部外板およびその内部の肋 板, 肋骨, 縦通材などの凹損およびき裂損傷があり, こ れらについては, 船首部に発生する過大な圧力との関係 で研究されている6)。

ところで，高速船舶では低気圧に遭遇したあと，上部 構造物の前端など主船体構造に接続し縦曲げ応力による 応力集中をらける部分に, 疲労に起因すると思われるき 裂が発見されることがあるといわれている。一般に、ひ とつの低気圧に遭遇するのは数時間から十数時間である こと，またこのような損傷の発生は老朽船に限られてい 
るわけではないことを考慮すると, この問題の場合, 通 常の疲労強度検討では取扱われない荒天時のバウフレア 一・スラミングによって船体全長にわたり誘起されるホ イッピング応力の影響を検討する必要があると思われ る。本論文では, 低気圧に遭遇している時間を考慮し て，上述の低サイクル疲労き裂発生の可能性を検討する。

応力集中の発生する個所としては, 開口周辺および上 部構造物の端部がよく知られている。船橋楼の前端を考 光ると，ここに作用する応力は非線形影響を考慮した主 船体の縦曲げ応力, 主船体のホイッピング応力, および 上部構造物のホイッピングによる連成振動（いわ㠴るシ ヤダー）による応力が考光らる。本論文では, 大型の高 速コンテナ船について船速・波高を各種变化させた場合 のホイッピングによる応力を計算し, 応力集中部の応力 集中係数之使用材料の S-N 曲線が与光られた場合につ いて低サイクル疲労強度に及洔す船速と波高の関倸を研 究した。本研究によると, 比較的綐曲げモーメントに対 する非線形影響の小さい船体後半部に打いても，ホイッ ピング応力は無視できず，特汇波高中を高速航行する 埸合には，ホイッピング応力成分の重畳により応力集中 部の疲労寿命は大幅任下する可能性のあることが明ら かとな⿰た。このような現象は，高速コンテナ船のみな らず，北太平洋などの荒天海域を航行する大型の高速船 舶について一般に問題になりらると思われる。

\section{2 高速コンテナ船の規則波中非線形応答 解析}

\section{1 計算対象船および構造のモデル化}

規則波中心非線形影響を含む動的弾性応答解析に供し た高速コンテナ船の主要目および body plan をとれぞ れ, Table 1, Fig. 1 に示す。李た, 構造のモデル化に 際して必要な断面 2 次モーメント $I$, せん断面積 $A_{s}$, 拉よび重量分布 $W$ は Fig. 2 のように仮定した。

上部構造物法云の長さと高さが同程度であることを考 虑し，前後方向へのせ九断変形のみを生ずるせん断はり と仮定した。Fig. 3 に示すモデル化に従えば，第 $i$ 甲板 の質量支集中質量 $m_{i}$ として経験的に

$$
m_{i}=250 b_{i} l_{i}(\mathrm{~kg}) .
$$

ここに，第 $i$ 甲板の幅と長さをそれぞれ $b_{i}(m), l_{i}(m)$ とする。类㐫，各 $i \sim i+1$ 甲板間のせん断剛性 $k_{\imath}$ は

Table 1 Principal particulars of a container ship

\begin{tabular}{lr}
\hline L : Length between perpendiculars & $245.0 \mathrm{~m}$ \\
$\mathrm{~B}:$ Breadth moulded & $32.2 \mathrm{~m}$ \\
$\mathrm{D}:$ Depth moulded & $24.0 \mathrm{~m}$ \\
$\mathrm{~d}:$ Draft & $11.0 \mathrm{~m}$ \\
$\mathrm{C}_{\mathrm{t}}:$ Block coefficient & 0.57 \\
W : Displacement & 51,000 ton \\
\hline
\end{tabular}

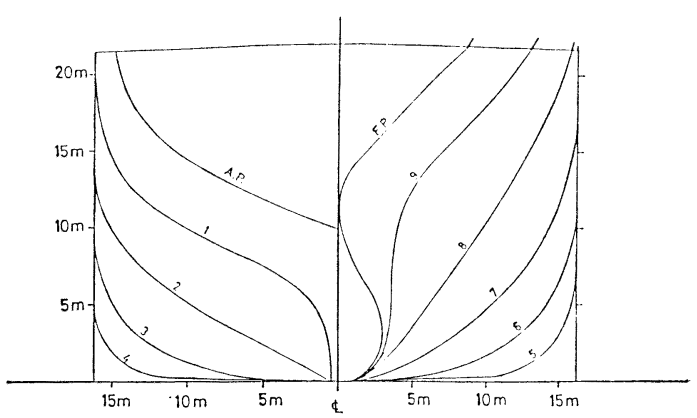

Fig. 1 Body plan of a container ship

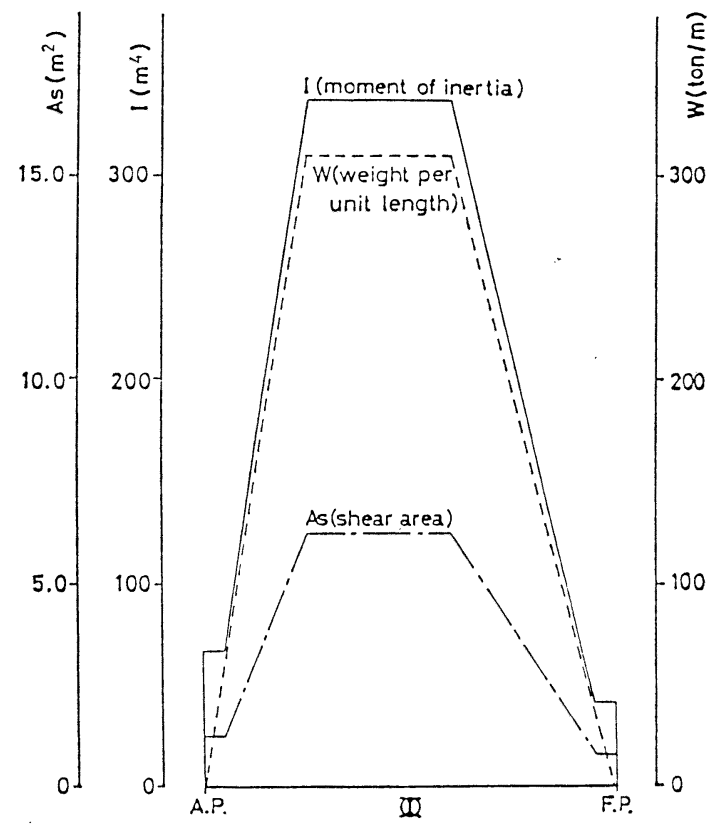

Fig. 2 Distributions of weight, moment of inertia, and shear area of a container ship

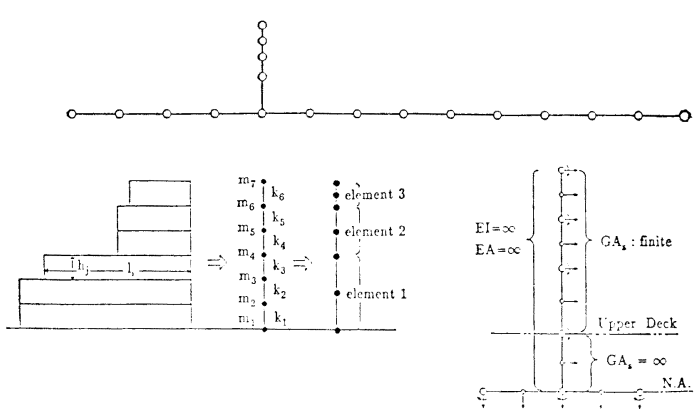

Fig. 3 Structural modelling of a container ship; overall modelling (top), and modelling of a superstructure(bottom) 


$$
k_{i}=G A_{s i} / h_{i}
$$

となる7)。ここにGはせん断弾性係数， $A_{s i}$ および $h_{i}$ はそれぞれ第 $i \sim i+1$ 甲板間の有効せん断面積と高さで ある。

構造のモデル化には, 要素中央に内部節点をもつせん 断変形を考慮したチモシェンコはり要素を用い8)，主船 体および上部構造物を一体として変断面はり近似する。

Fig. 3 に示すモデルに従い, 主船体は 40 要素, 上部構 造物は 3 要素とし, 上部構造物基部と主船体中立軸の間 は剛要素によって接続した。なお, 上部構造物の総重量 は700 ton とした。計算に用いたナング係数，せん断弾 珄係数はそれぞれ $21,000 \mathrm{kgf} / \mathrm{mm}^{2}, 8,100 \mathrm{kgf} / \mathrm{mm}^{2}$, また対数減衰率（2 節）は類似船9)より 0.056 とした。

\section{2 静水中における固有モードの解析}

前節で定めたデータおよびモデル化に従い，上部構造 物を有する船体の静水中に拈将る固有值解析を行い, 固 有振動数, 固有モードを定めた。Table 2 に上部構造物 を考虑した場合の第 15 次までの振動の周期を, 主船体 のみの振動の場合と比較して示す。Fig. 4 に各次数の固 有モードを示すが, 上部構造物と主船体との連成振動は 7 節の弾性振動モードから高次側で生じていることがわ かる。また，主船体の 12 節と 13 節の振動数の間に, 上部構造物の 1 次の振動モードが現われる。高次振動に ふ横断面内の振動との連成，付加質量と曲げ剛性の低下 などが影響するが，本解析では考慮しない。

\section{3 波浪中におけるホイッピングを考慮した曲げモ 一メントとシャダー}

波浪中航起時のスラミングによって誘起されたホイッ ビング成分を含む曲げモーメントを定めるため動的応答 の数值副算を行う。SR 125 の資料 ${ }^{10)}$ によれば，大型の 高速コンテナ船に扩いて目視波高 $3 ， 4 \sim 10 \mathrm{~m}$ の海象で 船速 $15 \sim 30 \mathrm{kt}$ 程度の実船航海の記録があるので, 本研 究では, 船長・波長比 1 の正面向い波状態で規則波の波 高を 6，8，10，12m の4通り，また船速については $6,10,14,18,22,26 \mathrm{kts} . の 6$ 通りに変化させたシリ ーズ計算を行った。

Table 2 Natural periods and frequencies

\begin{tabular}{|c|c|c|c|c|c|c|}
\hline \multirow[b]{3}{*}{ mode } & \multicolumn{4}{|c|}{ WI eirion } & \multicolumn{2}{|c|}{ superstructure } \\
\hline & \multicolumn{2}{|c|}{$\begin{array}{l}\text { without } \\
\text { cuperstruoture }\end{array}$} & \multicolumn{2}{|c|}{$\begin{array}{l}\text { : th } \\
\text { sunerstructure }\end{array}$} & \multirow[b]{2}{*}{$\begin{array}{l}\text { Feriod } \\
(\text { sec.) }\end{array}$} & \multirow[b]{2}{*}{$\begin{array}{l}\text { frequency } \\
(\mathrm{cpm})\end{array}$} \\
\hline & $\begin{array}{l}\text { Feriod } \\
(\mathrm{sec})\end{array}$ & Srentesy & Fariod & $\begin{array}{l}\text { frequency } \\
\text { (cpm) }\end{array}$ & & \\
\hline 1 & 8.903 & 6.74 & 0.903 & 6.74 & & \\
\hline 2 & $\varepsilon .091$ & 7.42 & $\varepsilon .093$ & 7.41 & & \\
\hline 3 & 1.027 & $5=\ldots$ & 1.020 & 58.39 & & \\
\hline 4 & $c .453$ & an. & 0.453 & 132.41 & & \\
\hline 5 & 0.269 & 222.33 & 0.262 & 222.74 & & \\
\hline 6 & $c .185$ & 5.5 .19 & 0.185 & 324.51 & & \\
\hline 7 & 0.138 & 435.06 & 0.138 & 434.91 & & \\
\hline 8 & $c .1 c y$ & 5.200 & 0.19 & 548.40 & & \\
\hline 9 & 0.090 & 601.50 & 0.091 & 662.46 & & \\
\hline 10 & C.c77 & $r=0,0$ & .7 & 781.32 & & \\
\hline 11 & 0.067 & 82.69 & .067 & 898.44 & & \\
\hline 12 & C.c5) & 1050 & 0.060 & 1009.00 & & \\
\hline 13 & 0.053 & 1131.87 & 0.054 & 1122.14 & & \\
\hline (1) & $c 0$ & 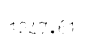 & 13 & 1248.27 & 0.051 & 1166.64 \\
\hline
\end{tabular}
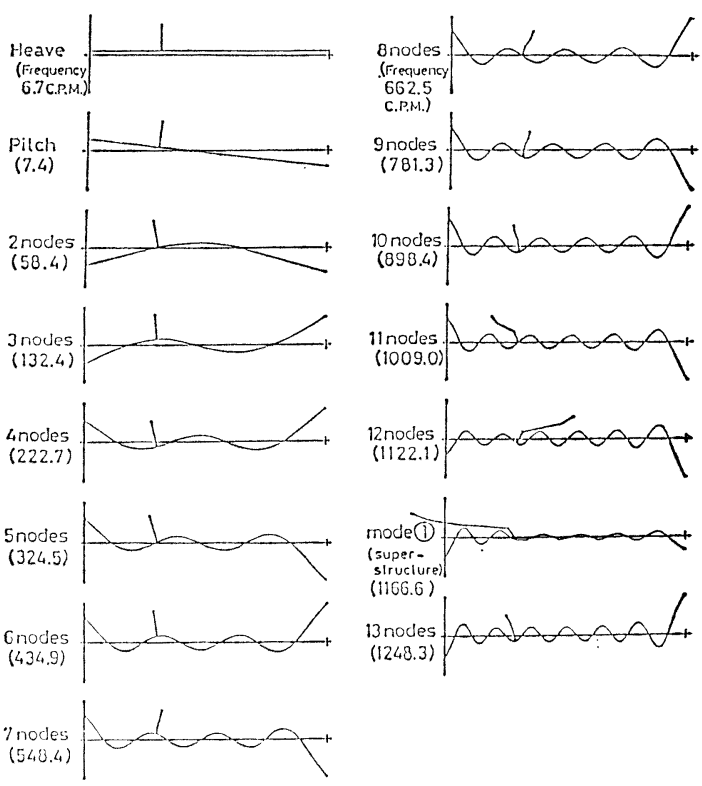

Fig. 4 Eigen modes of vibration of a container ship

計算に際しては，前節で求めた剛体モード $2 つ と 2$ 節および 3 節モードの計 4 モードを用い, 時間積分には Newmarkのß法を採用した。時間積分における時間刻 みは, 一出会周期の 1/300 を標準とし， 6 出会周期間の 計算を行った。なお，船体運動が注ぼ定常になるまでの 初めの 4 出会周期については構造減衰を大きくとり, 後 続の応力波形に対するホイッピングの影響を除き, 最後 の 2 出会周期についてホイッピングの重畳による曲げモ ーメントの増加を検討することとした。

上部構造物の振動には, 高次振動の成分が関係する可 能性があるので，この影響を検討するため 13 節までの 高次モードを入れた計算も行った。この場合の時間刻又 は 1 出会周期の $1 / 2,000$ とした。

動的曲げモーメントの船長方向の分布は, 上部構造物 との結合位置で不連続となるはずであるが, 数值計算結 果によるとそのような影響は極めて小さく, 結合部上部 構造物側に生じるモーメントは主船体当該部のそれの $1 \%$ 程度であり無視できることがわかった。各計算条件 に拈ける最大モーメントの包らく線を Figs. 5〜8 に示 す。同一の波高に扎いて船速を増加させるとスラミング およびその後のホイッピングの影響によってサギング側 のモーメントが著しく増加する。文献 [11]などに示さ れる剛体モードのみを含むモーメントの計算の場合には 非線形影響が主として船体前半部のサギングモーメント の増加に現われるのに対して，ホイッピング成分を含む 本計算の場合には, 高速航走時の最大ホギングモーメン トの増加も無視できず, またモーメントの増加する範里 


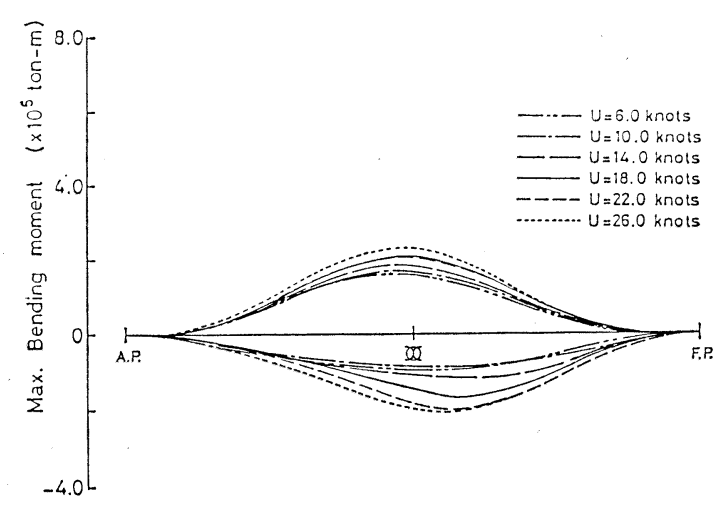

Fig. 5 Longitudinal distribution of maximum bending moment including whipping components $\left(H_{w}=6.0 \mathrm{~m}\right)$

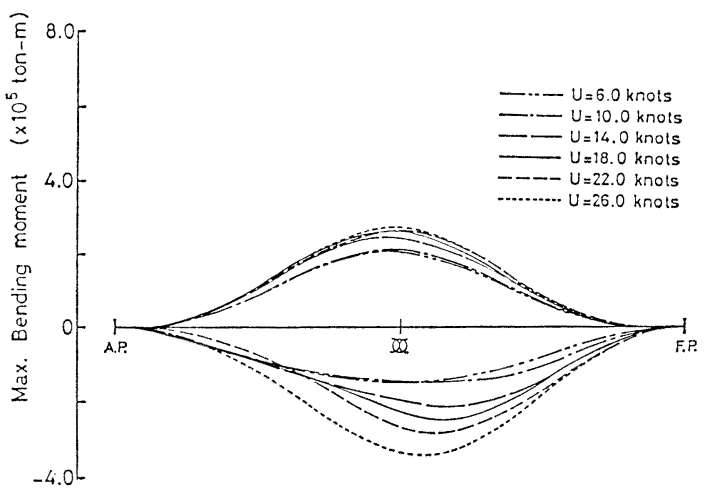

Fig. 6 Longitudinal distribution of maximum bending moment including whipping components $\left(H_{w}=8.0 \mathrm{~m}\right)$

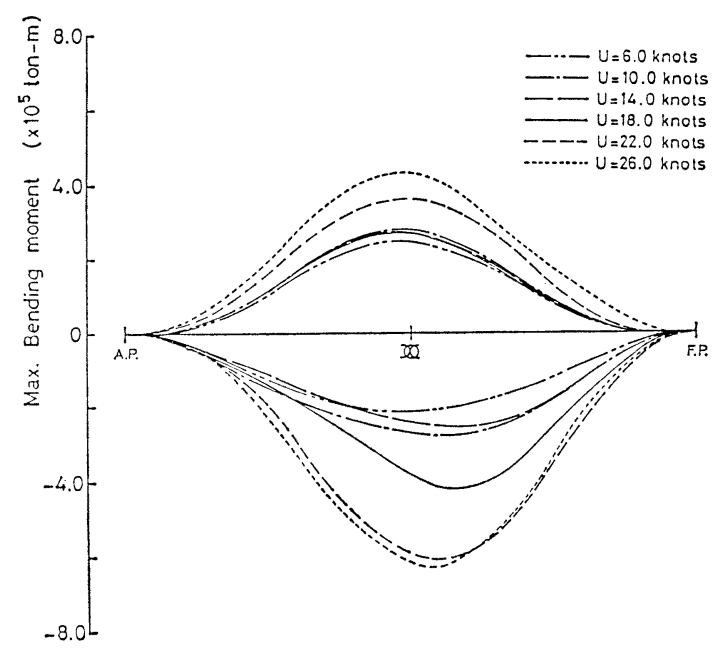

Fig. 7 Longitudinal distribution of maximum bending moment including whipping components $\left(H_{w}=10.0 \mathrm{~m}\right)$

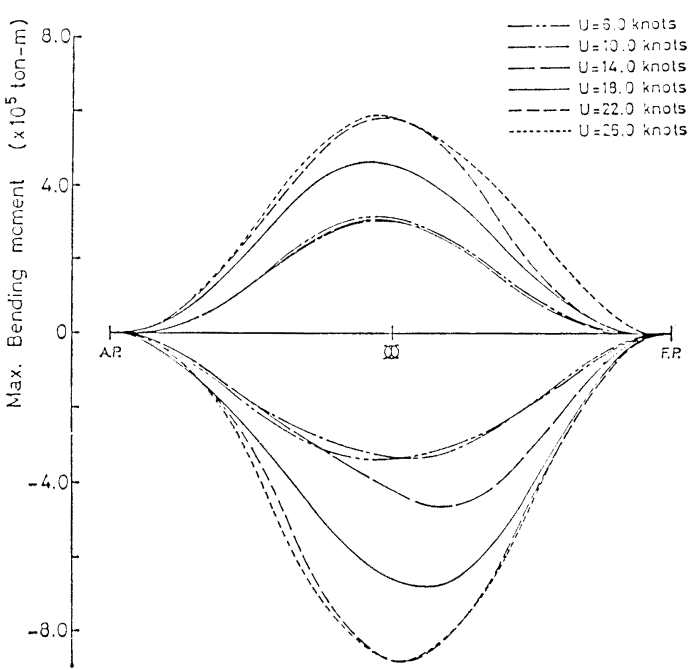

Fig. 8 Longitudinal distribution of maximum bending moment including whipping components $\left(H_{w}=12.0 \mathrm{~m}\right)$

も船長の全長にわたることもこれらの図から明らかであ る。このことは, 疲労き裂の発生寿命が応力振幅の増加 によって急激に短かくなることと関連して重要な点であ ると思われる。

上部構造物前端部近傍 SS $3^{1} / 2$ 亿予ける主船体曲壮こ 一メントの時刻歴について考察する。Fig. 9 に波高 6 $\mathrm{m}$, 速力 $14 \mathrm{kt}$ の場合の曲げモーメントおよび甲板応力 の時刻歷を示す。この場合も含め波高が $6 \mathrm{~m}$ の場合には 船底スラミングは発生しない。曲げモーメントに重睤す るホイッピング成分は主としてバウフレア・スラミング に誘起されたものと考光られる。波高が $8 \mathrm{~m}$ 以上になる と，注ぼすべての場合について船底露出が生じるが，船 底没水時に受ける衝撃力よりはバウフレア没入時にうけ る流体力およびその後に生じるホイッピング応力の重量 がサギングおよびホギングモーメントの最大值に大きな 影響を与えていることが Figs. 10, 11 の例からもわか る。この図において一旦露出した船底が没水し, スラミ ングの発生している範囲をロで示した。Figs. 9〜11を 比較すると船速および波高の增加に伴い, 曲げモーメン トに占めるホイッピング成分が極めて大きくなることが 理解されよう。

上部構造物自体の振動とそれに伴って側部に生じるせ ん断力が上部構造物の強度に及ぼす影碧を波高 $8 \mathrm{~m}$, 速 力 $18 \mathrm{kts}$ の場合を例にとって榆討する。この計算に際 しては, 上部構造物の固有振動モード(1)を含むように用 体モードの外, 主船体 13 節の振動モードまで入れた応 答解析を行っている。船首部にスラミングが発生する と, その後の主船体のホイッピングによって上部構造物 は前後振動する。Fig. 12 に船橋位置における前後加速 


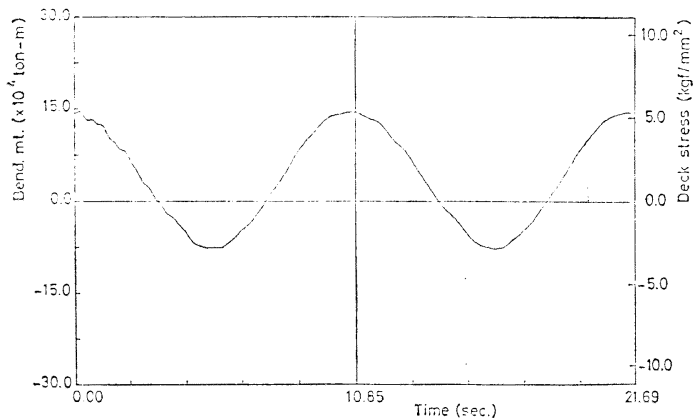

Fig. 9 Time history of bending moment at S. S. $3-1 / 2\left(H_{w}=6.0 \mathrm{~m}, U=6.0 \mathrm{knots}\right)$

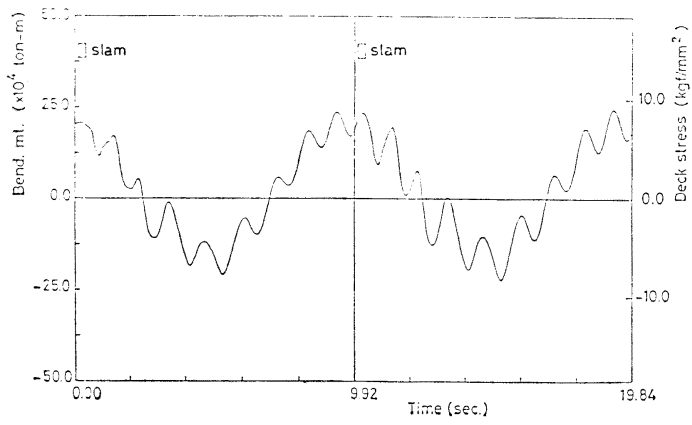

Fig. 10 Time history of bending moment at S. S. $3-1 / 2\left(H_{w}=10.0 \mathrm{~m}, U=10.0 \mathrm{knots}\right)$

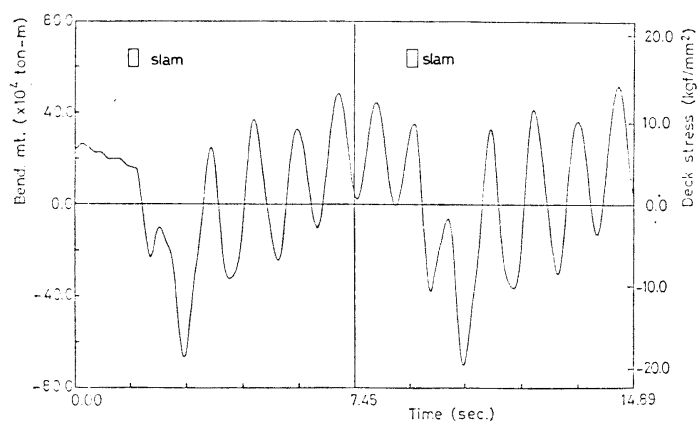

Fig. 11 Time history of bending moment at S. S. $3-1 / 2\left(H_{w}=12.0 \mathrm{~m}, U=26.0\right.$ knots $)$

度の時刻歴を示すが，スラミング発生後約 1 秒間にわた 门主船体 7 節程度の高次振動により小刻みの前後振動を した後, 主船体 2 節振動に対応する上部構造物の前後振 動が続?。これは文献〔10]などでシャダーと呼ばれて いる現像に対応すると思われる。このような上部構造物 のせん断振動によって発生するせん断応力の時刻歴も Fig. 12 と類似の形を示すが数值的には $0.1 \mathrm{kgf} / \mathrm{mm}^{2}$ 程 度と極放て小さ強度上は無視して差しつかえないこと ぶうかった。したがって上部構造物端部の疲労強度を検 討する場合であっても主として主船体の低次弾性振動モ ードによるホイッピング応力までを含めて考えれば十分

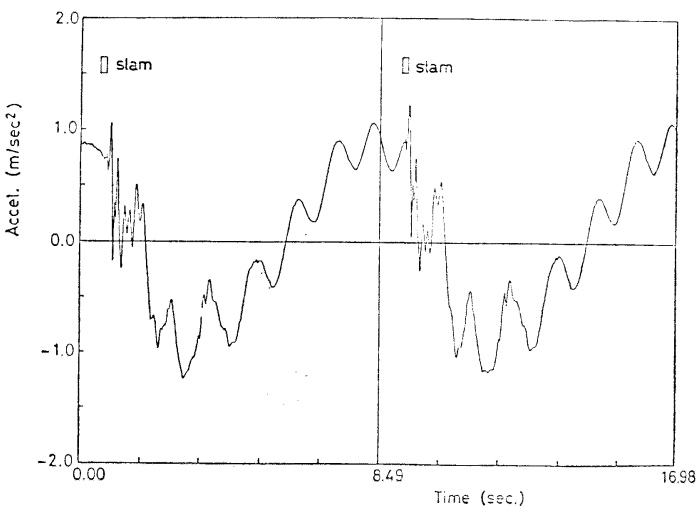

Fig. 12 Time history of longitudinal acceleration at Nav. deck $\left(H_{w}=8.0 \mathrm{~m}, U=\right.$ 18.0 knots)

である。

本計算によって, 上部構造物のシャダーがホイッピン グに伴って現われることが示されたが，その振動数が上 部構造物の固有振動数よりは低い值であることに注意し たい。上部構造物頂部シャダーは不快感の原因にはなり らるが, 船体強度には影響しないことが明らかとなった。

\section{3 応力集中部の疲労強度に関する考察}

\section{1 一出会周期当たりの疲労被害度}

船体がスラミングをらけ，その後大なるホイッピング 応力を生じる場合, このような動的応力が船体応力集中 部の疲労き裂発生にどのような影響を与えるにかついて 考察する。 S-N 線図を Fig. 13 に示す。これは, 文献 [12]に示される軟鋼のガス切断部に対する平板の片振 り疲労試験結果, I 型はりを用いた連続隅肉溶接部の曲 げ疲労試験結果, および十字隅肉継手の軸力片振り病学 試験結果をもとに, 平均応力 $\sigma_{m}$ の影響を考慮して両振り の場合にも应張して適用すべく作成された線図である。

ホイッピング応力のような変動するくり返し応力をら ける場合の, くり返し数拈よび応力振幅 $S_{a}$ あるいは応 力範囲 $\Delta S$ の定め方として, 本研究では一出会周期を一 回のくり返しとし，その周期内のホイッピング成分の重 畳した応力時刻歴のホギング側とサギング側の最大值の 差を応力範冉とする。この仮定の妥当性を検討するた め, 一出会周期の応力時刻歴に詨してレインフロー法 ${ }^{13)}$ を適用して疲労被害度を計算すると，汪とんどの船速・ 波高の組合わせに対して上述の仮定にもとづく值の 1 2 割増程度であり問題のないことが確認できた。なお， ホイッピング応力成分が最も著しい波高 $12 \mathrm{~m}$, 船速 26 kts. の場合 (Fig. 11) は例外的にレインフロー法による 疲労被害度が上述の仮定によるものの 2 倍程度の值とな った。いずれにしても, 波浪縦曲げ応力にホイッピング 成分が重畳し，ホギング，サギングそれぞれの応力の最 


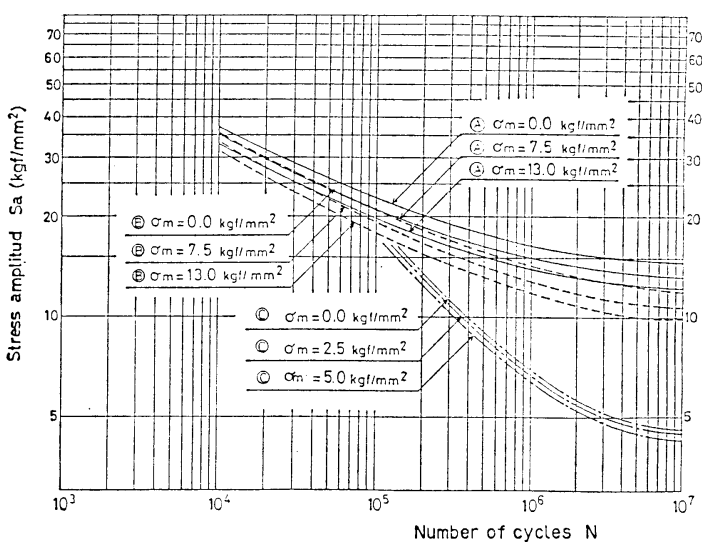

Fig. 13 S-N curves, where (A), (B), and (C) represent each fatigue curve for gas cut surface, continuous fillet welded joint loaded in fillet welding direction, and cross-shaped fillet welded joint loaded perpendicular to fillet welding direction

大值を増加させることが重要と考えられる。

船長方向各位置に発生するくり返し虑力の振幅は Figs. 5〜8 に示す曲汭モーメントを各位置の断面係数で 除して定めることができる。本節では，上部構造物端部 近傍 SS $3^{1} / 2$ に和ける甲板応力を基準応力とし, 構造 詳細によって定まるその近傍の応力集中部の応力集中係 数をパラメータとして, 一出会周期に対する疲労被害度 $D_{e}$ を検討する。各波高・船速に対するホギング側・サ ギング側の応力の最大值からまず応力範囲を定市, さら に軵造的要因による引張り残留応力を $10 \mathrm{kgf} / \mathrm{mm}^{2}$ とし て Fig. 13 を用い対応する平均応力の S-N 線図を内插 により求め $D_{e}$ を定める。Fig. 14 に波高 $8 \mathrm{~m}$ の場合に ついて船速を増加させたときのガス切断部の疲労被害度 の増加の様子を応力集中係数を $2.0,2.5,3.0,3.5$ と 変化させて図示する。この図から疲労被害度は船速に関 して対数的に増加することがわかる。Fig. 15 に同じく 波高 $10 \mathrm{~m}$ の場合を示すが，図中に $U_{c}$ と示した $18 \mathrm{kts}$. 以上の速力で急激に疲労被害度が増加し, 特に応力集中 係数 3.0 以上の高応力部では, 延べ数日間このような状 態が続くと疲労き裂発生の危険性があることがわかる。 Fig. 13 に示した疲労強度の最も低い十字隅肉継手部に ついて, 波高 $8 \mathrm{~m}$ の場合の一出会周期当たりの疲労被 害度を示したのが Fig. 16 である。この場合には, 応力 集中係数 2.0 以下のときについても Fig. 14 に示すガス 切断部にくらべ高い疲労被害度が算出される。

\section{2 応力集中部の疲労強度に及ほす波高と船速の影} 響

前述のように確定的に定まる一出会周期当たりの疲労

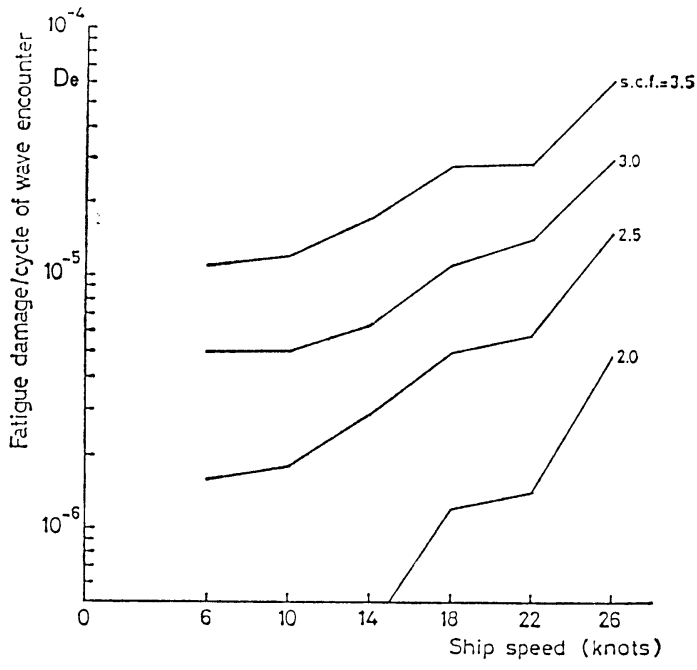

Fig. 14 Fatigue damage per a cycle of wave encounter $\left(H_{w}=8.0 \mathrm{~m}\right.$, gas cut surface)

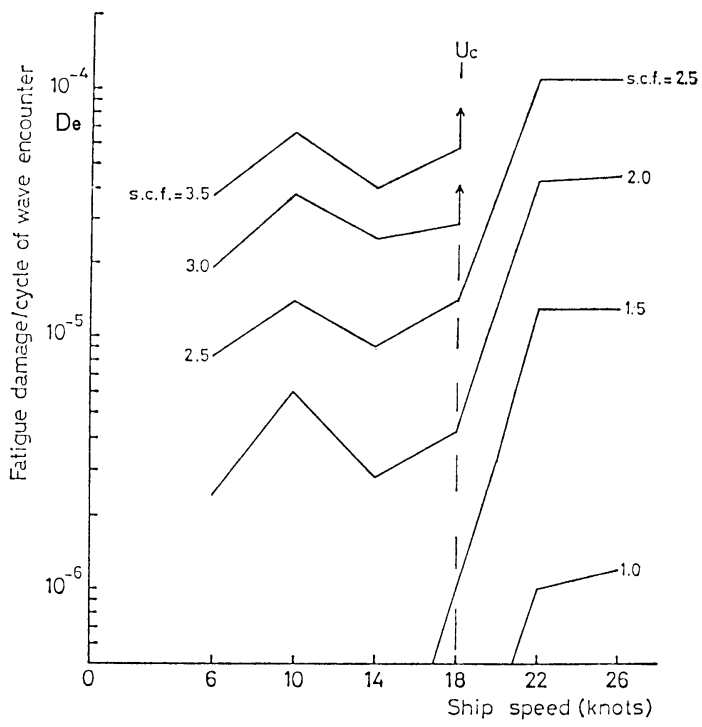

Fig. 15 Fatigue damage per a cycle of wave encounter $\left(H_{w}=10.0 \mathrm{~m}\right.$, gas cut surface)

被書度のみから，実際の不規則波中を各種の出会角で航 行する船舶の疲労強度を海象の長期確率をもとに定める のは困難である。本節では以下の仮定のもとに痕労強度 と波高, 船速の関係を検討した。

（1）疲労き裂の発生に関係する高い縦応力が作用す るのは, ホイッピングが生じる可能性のある有義波高 $6 \mathrm{~m}$ 以上の短期海象に限る。

（2）北米航路のコンテナ船に拈いて，スラミングを 伴う厳しい時化に遭遇するのは, 主として冬季西航時, 


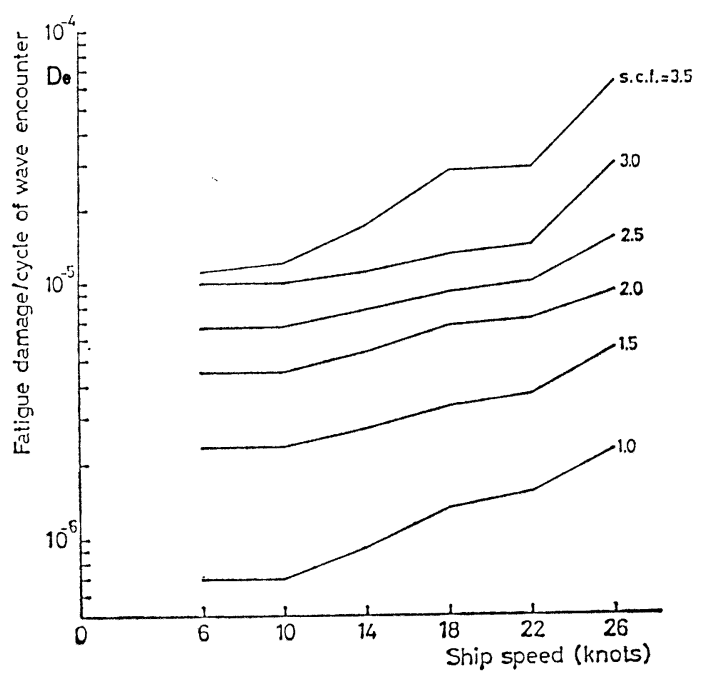

Fig. 16 Fatigue damage per a cycle of wave encounter $\left(H_{w}=8.0 \mathrm{~m}\right.$, cross-shaped fillet welded joint loaded perpendicular to fillet welding direction)

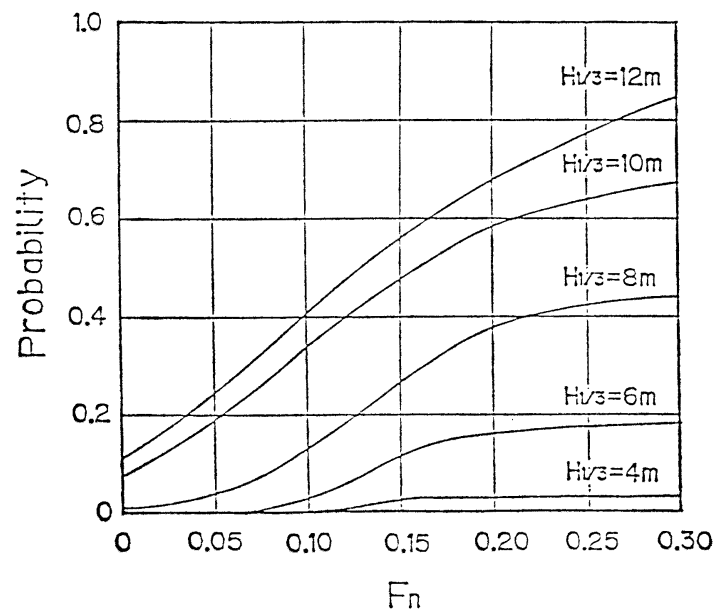

Fig. 17 Probability of occurence of slam per a cycle of wave encounter in head seas (Mariner type ship; see Ref. [14])

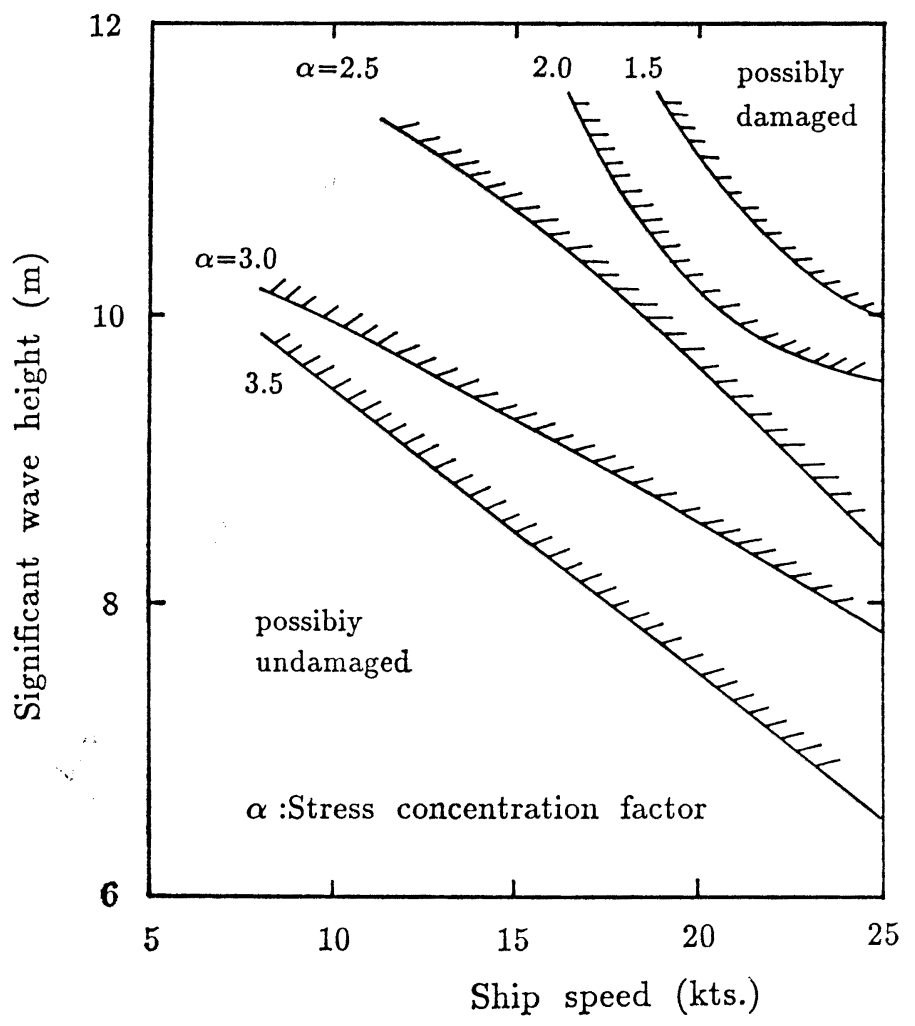

Fig. 18 Prediction of possible fatigue damage for a period of 1 year in relation to wave heights, stress concentration factors, and ship speeds 
特に北西太平洋海域航行時であるから，ホイッピングを 発生するょらな海象に遭遇するのは, 年間高々延 10 日 (くり返し数 $10^{5}$ 回) 程度である。

（3）不規則な実海面に求いて一出会周期汇対してホ イッピングを伴うスラミングを発生する確率 $P_{s}$ は，マ リナー型船舶汶対する Ochi ${ }^{14)}$ の結果汇従うとする。た だし，Fig. 17 に示すように，有義波高とフルード数を 用いた表現に改め本船に適用する。

（4）ホイッピングが発生する場合一出会周期内にう 计る疲労被害度 $D_{e}$ は，有義波高と等しい波高をもつ船 長・波長比 1 の向い波規則波によるもの（3.1 節にて算 出）とする。これは安全側の仮定である。

（5）各有義波高, 船速, 応力集中係数汇拈计る疲労 寿命 (時間) は平均出会周期を $T_{e}$ として $T_{e} /\left(D_{e} \cdot P_{s}\right)$ とする。

以上の仮定から，船体構造部材の使用寿命（期間）を 与えた場合に，各応力集中係数に対してこの期間でちょ らど疲労き裂が発生するような有義波高と速力の関係が 得られる。Fig. 18 は一例として，き裂発生までの期間 を 1 年 (平均出会周期 $T_{e} \simeq 9 \sec$ としてくり返し数 $10^{5}$ 回）の場合の母材ガス切断部に対する関係である。各曲 線上の状態に対する一出会周期当たりの疲労被害度の期 待值 $D_{e} \cdot P_{s}$ は一定であるから，少なくともこの曲線の 左下側領域に入るような状態で運航を行えば，与兄られ た期間内に対する疲労き裂発生防止の十分条件を満足す ると考兄られる。

\section{4 結 論}

高速コンテナ船のスラミングに伴うホイッピング応力 を計算するとともにその応力集中部の疲労強度に与える 影響を考察し, 以下の結論を得た。

（1）一出会周期当たりの疲労被害度が波高および応 力集中係数に関して対数的に増加するのは当然である が，ホイッピング応力が重畳する場合には，船速の増加 に対しても同様の傾向があることが明らかとなった。特 に大波高時には疲労被害度が急激に増大寸る限界船速が 㟧る。

（2）上述の疲労被害度とOchi によって示されたス ラミング発生確率を用いると, 使用期間中に応力集中部 の疲労き裂発生を防止するための, 波高, 船速, 応力集 中率の関係を定めることができ，これは荒天時の減速あ るいは構造詳細改善の指針となる。

（3）上部構造物端部に相当する SS $3^{1} / 2$ 近傍の場 合, 剛体モードのみを含む解析では曲げモーメントの非 線形影響による増加は注とんどないが，弾性振動モード を含めるとホイッピングによるモーメントの增加が著し い。ホイッピング応力の評価には, 主船体の低次の弾性
モードを含めれば十分である。

（4）上部構造物のシャダーの発生人カニズムが明ら かになった。シャダーによる騒音および不快感の発生の 可能性はあるが，強度に関しての影篮は無視できる。

\section{謝 辞}

本研究に際し資料を提供していただいた三菱重工業株 式会社神戸造船所の各位，およびレインフロー法につい て御教示いただいた船舶技術研究所井上肇部長に謝意を 表します。な扔, 数值計算には横浜国立大学計算機セン ターの HITAC-M $240 \mathrm{H}$ を使用した。

\section{参考 文 献}

1）運輸省船舶局：尾道丸事故に倸る技郝裕討会報告 書, 1981, 運輸省.

2）山本，藤野，大坪，深沢，䂟井，青木，渡㲽，池 田, 熊野, 黒岩: バラ積運搬船の满載時における 遭難事故解析, 日本造船学会論文集, 第 154 号, 1983. pp. $516 \sim 524$.

3）山本, 飯田, 深沢, 村上, 荒井、安東: 高速コン テナ船のスラミングによる船首部損㑺解析, 日本 造船学会論文集, 第 155 号, 1984, pp. 246 256.

4）井上, 前中：低サイクル疲労破壞実娩及び座屈䇢 所の破壞強度, 異常海難防止システムの総合研究 開発特別講演会講演集, 運輸省運輸政策局, 1987, pp. $63 \sim 75$.

5）南，小川，木村：繰返し衝撃重置下の低サイクル 腐食疲労, 日本造船学会論文集, 第 130 号, 1971, pp. 321 327.

6）西部造船会：NBFD 小委員会最終報告書， 1987.

7) VERITEC : Vibration Control in Ships, 1985, Norway.

8）大坪，黑岩，山本：大波高波浪中の船体構造応答， 日本造船学会論文集, 第 157 号，1985，pp. 391～ 402.

9）山本，藤野，深沢：非線形性を考虑した波浪中の 船体綎運動および縦強度 (第 3 報), 日本造船学 会論文集，第 145 号，1979，pp. 63〜70.

10）第 125 部会報告書：超高速コンテナ船の耐航性に 関する研究，日本造船研究協会資粘 $(1972,1973)$

11）黑岩, 大坪：溲型船に拈けるサギングモーメント の非線形性, 日本造船学会論文集, 第 161 号, 1987, pp. $234 \sim 241$.

12) Svetskommissionen Ingeniorsvetenskapsakademien, Monograph on Fatigue Strength of Weld Section 1, Royal Swedish Academy of Engineering Sciences, Stockholm, 1969.

13）遠藤，安在：簡明にされたレインフローアルゴリ ズム「P/V」差法について, 材料, 第 30 卷, 328 号, 1981, pp. 89 93.

14) M. K. Ochi : Extreme Behavior of a Ship in Rough Seas-Slamming and Shipping of Green Water, TSNAME, Vol.72, 1964, pp. 143 202. 